\title{
EUROPEAN ACCREDITATION AGENCY'S VIEW ON KAZAKHSTAN'S ENGINEERING AND INFORMATION TECHNOLOGY HIGHER EDUCATION
}

\author{
Andreas Ahrens \\ Hochschule Wismar, Germany \\ Martin Foerster \\ Accreditation Agency for Study Programs in Engineering, Informatics, \\ Natural Sciences and Mathematics, Germany \\ Jeḷena Zaščerinska \\ Centre for Education and Innovation Research, Latvia

\section{Iring Wasser} \\ Accreditation Agency for Study Programs in Engineering, Informatics, \\ Natural Sciences and Mathematics, Germany
}

\begin{abstract}
In the era of digital economy, there is an urgent need in highly qualified engineering and Information Technology (IT) specialists in Kazakhstan. The aim of the research is to analyse the needs of higher education in the field of engineering and IT in Kazakhstan underpinning elaboration of implications for higher education in the field of engineering and IT in Kazakhstan. The empirical study was carried out in October 2019. Exploratory study was implemented. Interpretive paradigm was employed in the present work. Non-structured interview served as the basis for data collection. Content analysis was performed for data analysis. Findings of theoretical analysis allow extending three-component model on needs analysis, namely experts' perspective, educators' perspective, and students ' perspective by the fourth component, namely community perspective. Implications for higher education in Kazakhstan are formulated as following: universities delivering higher education in the field of engineering and IT in Kazakhstan need to balance academic and practical components in their study programmes; interaction between educators and students, on the one side, as well as enterprises, companies and industry, on the other side, should be enhanced in higher education in the field of engineering and IT in Kazakhstan. Directions of future work are proposed.
\end{abstract}

Keywords: accreditation agency view, engineering and Information Technology, expert perspective, higher education, needs analysis, non-structured interview, opinion. 
Ahrens et al., 2020. European Accreditation Agency's View on Kazakhstan's Engineering and Information Technology Higher Education

\section{Introduction}

The contemporary development of world economy focuses on the concept of digital economy.

In Kazakhstan, the Government Programme entitled Digital Kazakhstan (Digital Kazakhstan, 2017) was proposed by the President of Kazakhstan in his address "Third modernization of Kazakhstan: Global Competitiveness" to his Nation on the 31st January 2017. The goal of the Government Programme Digital Kazakhstan is the progressive development of the digital ecosystem in Kazakhstan.

Integration of the concept of digital economy as well as the Government Programme Digital Kazakhstan into a local market requires a number of highly qualified specialists, in particular engineers and Information Technology (IT) professionals. The data obtained from other studies (Ahrens, Gruenwald, Zascerinska, Zakirova, Yefimova, Kakabayev, Melnikova, \& Aleksejeva, 2018) reveals that

- There is an urgent need in Information and Communication Technologies (ICT) or, in other words, IT specialists in Kazakhstan;

- Enterprises and industry require specialists with "hybrid knowledge and skills", namely a combination of knowledge and skills in IT and another professional domain that focuses on automatisation of professional activity (Digital Kazakhstan, 2017, p. 14);

- Such a combination as Information Security and Data Management is on high demand in most enterprises and industry:

- Universities has to focus on ICT or, in other words, IT education at master level in order to increase the number of teaching staff with a scientific degree for IT education quality assurance.

Traditionally, preparation of qualified specialists is delivered by the education sector, and, in particular, highly qualified specialists - by higher education institutions.

The aim of the present paper is to analyse the needs of higher education in the field of engineering and IT in Kazakhstan underpinning elaboration of implications for higher education in the field of engineering and IT in Kazakhstan.

The novel contribution of the paper is the newly formulated implications for higher education in the field of engineering and IT in Kazakhstan.

\section{Literature review}

Higher education in the field of engineering and IT is shaped via needs analysis (Bassus, Ahrens, \& Zascerinska, 2015). Conventionally, needs analysis 
is proposed to be carried out from three perspectives as shown in Figure 1 (Zascerinska, 2013).

\section{Experts' view}

\section{Needs analysis}

Students' view

\section{Educators' view}

Figure 1 Three perspectives of needs analysis (Zascerinska, 2013)

It should be noted that a perspective is represented by a view. View is identified as individual's opinion based on his/her knowledge, skills and attitudes to a phenomenon (Ahrens, Zascerinska, Hariharan, \& Andreeva, 2016).

The inter-relations between the expert perspective and accreditation agencies are illustrated in Figure 2.

\section{Experts'perspective}

Accreditation agency

Figure 2 The inter-relations between experts' perspective and accreditation agency

Additionally, due to the society development, the theoretical analysis of the model on needs analysis from three perspectives allows extending the model on needs analysis to be carried out from four perspectives depicted in Figure 3.

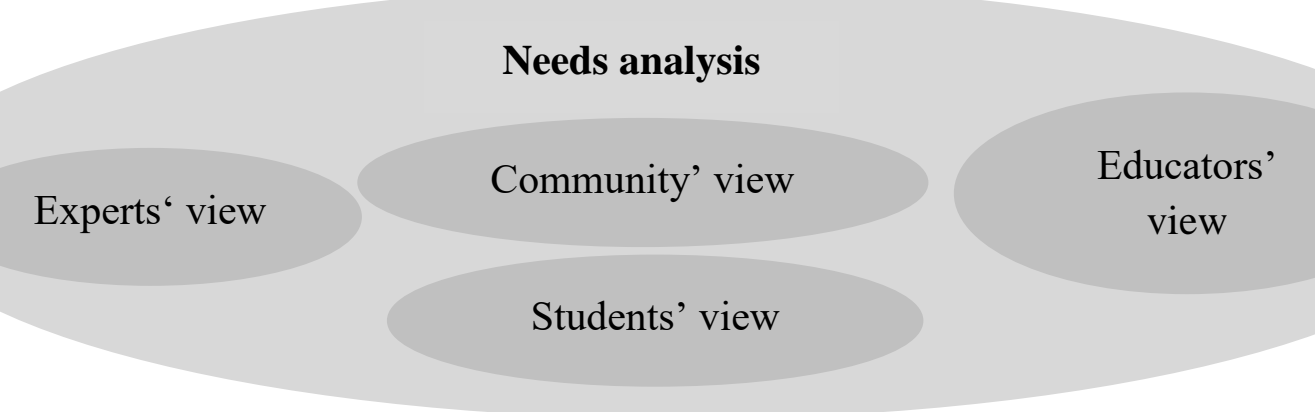

Figure 3 Four perspectives of needs analysis 
Involvement of community widens an understanding of social, philosophical, environmental, ethical and other contexts in which a complex engineering phenomenon is to be integrated, designed, constructed and maintained.

Against this background the present work will only focus on the expert perspective, namely view of an accreditation agency on higher education in the field of engineering and IT in Kazakhstan as accreditation agencies' view is important due to their efforts to secure and further expand high standards for the quality of higher education.

\section{Methodology}

The present part of the paper describes in detail the course of the present research. It should be emphasized that the present research includes an empirical study as its part. Consequently, the present research work proceeds from theoretical investigation through empirical study to drawing conclusions. As theoretical investigation and empirical study are different parts of research work, the aim of the theoretical investigation as well as the purpose of the empirical study differ, too. The aim of theoretical investigation is conventionally wider in comparison to the purpose of empirical study. Consequently, the research presented in the paper includes the use of theoretical as well as empirical methods.

The present research employs the qualitative methodology or, in other words, the course of the research and empirical study as content analysis as well as model creation are a qualitative process (Krippendorff, 2004). Qualitative process is a methodology mostly used within the interpretive approach (Thanh \& Thanh, 2015).

Interpretive research paradigm has been used in the present work. Interpretive paradigm is characterized by the researcher's practical interest in the research question (Cohen, Manion, \& Morrison, 2003). The researcher is the interpreter (Ahrens, Purvinis, Zascerinska, Miceviciene, \& Tautkus, 2018).

The choice of the methodology or, in other words, course of the research and empirical study was determined by a couple of factors: 1. The addressed phenomenon, namely higher education in the field of engineering and IT in Kazakhstan, was not investigated in detail. The previous study only focused on exploring ICT education at master level in the context of advancement of digital ecosystem in Kazakhstan (Ahrens et al., 2018). The uncertainty in this research field leads to the use of exploratory study or, in other words, methodology within the present work. 2. An exploratory study or, in other words, methodology is characterised by a high degree of flexibility and lack of formal structure. An exploratory study aims to identify the boundaries of the social environment in which the problems, opportunities or situations of interest are likely to reside. 
Social environment is synonymously used to the terms "social situation", "situation of interaction", "social interaction" and "social-cultural environment" (Ahrens \& Zascerinska, 2012). Consequently, social environment is based on social interactions. Hence, an exploratory study focuses on social interactions between

- experts,

- educators,

- $\quad$ students and

- wider society, including community.

It should be noted that by community, state's government, local government, non-governmental organisations and all the other interested organisationas as well as persons are meant.

The exploratory methodology of the present work (theoretical investigation and empirical study) (Ahrens, Bassus \& Zascerinska, 2013, p. 104) is shown in Figure 4 (Ahrens et al., 2018).

As the theoretical part of the present research work was aimed at modelling inter-relations between higher education in the field of engineering and IT, needs analysis, expert view and accreditation agency, theoretical methods implied analysis of theoretical sources and theoretical modelling (Ahrens, Zascerinska, \& Melnikova, 2019).

\section{Exploratory methodology}

Phase 1

Exploration

Phase 2

Analysis

Phase 3

Hypothesis/Question

Development

Figure 4 Three phases of exploratory methodology

The design of the present empirical study traditionally implies

- the question,

- purpose,

- sample, and

- methodology and methods of the empirical study. 
Ahrens et al., 2020. European Accreditation Agency's View on Kazakhstan's Engineering and Information Technology Higher Education

The guiding question of the empirical study was as follows: What are university needs in delivering higher education in the field of engineering and IT in Kazakhstan?

The purpose of the empirical study was to analyse the view of a European accreditation agency on higher education in the field of engineering and IT in Kazakhstan.

The empirical study was carried out in October 2019. The present empirical study involved one respondent. The qualitatively oriented empirical study allows sample composition of only few respondents (Mayring, 2004). Moreover, the respondents themselves are not of interest, only the conclusions and transfers we can draw from these respondents (Flyvbjerg, 2006). Selecting the respondents for the study comprises use of information-oriented sampling, as opposed to random sampling (Flyvbjerg, 2006). This is because an average respondent is often not the richest in information. In addition, it is often more important to clarify the deeper causes behind a given problem and its consequences than to describe the symptoms of the problem and how frequently they occur (Flyvbjerg, 2006). Random samples emphasizing representativeness will seldom be able to produce this kind of insight; it is more appropriate to select some few respondents chosen for their validity (Flyvbjerg, 2006). In order to save the information of the present research confidential, the respondent's name, surname and affiliation are not disclosed. The respondent summarised the experience of a European accreditation agency in Kazakhstan for about 20 years.

Data were collected via interview. Non-structured or, in other words, unstructured interview was implemented to search for the main categories of the research field (Kroplijs \& Rascevka, 2004, p. 99). Non-structured interview is conventionally built on a certain topic to be disclosed during the meeting. However, non-structured interview does not imply any specific set of predetermined questions. Non-structured interview is organised in a non-formal manner and tends to be open-ended. The non-structured interview was conducted during an international conference in Sibiu, Romania, in October 2019. As the interview was non-structured, the topic was only defined, namely university needs in delivering higher education in the field of engineering and IT in Kazakhstan. Non-structured interview was studied via content analysis. Further on, content analysis included such types as (Mayring, 2000) structuring content analysis and summarizing content analysis. Structuring content analysis assists in categorising the data in accordance to the previously determined criteria (Budde, 2005). In turn, summarizing content analysis seeks to reduce the material in such a way that the essential contents are preserved, but a manageable short text is produced (Mayring, 2004, p. 269). 


\section{Research Results}

The present part of the paper reveals the results of the interview and findings of the study.

Thus, the respondent emphasised that during the past 20 years a European accreditation agency has been heavily involved in developing the Kazakh higher education in the fields of engineering, natural sciences and IT. In total 264 degree programmes have been accredited at a broad variety of higher education institutions, most of them situated in the educative capital of the country, namely Almaty, but also including more remote and rural areas.

While being active over such a long period a European accreditation agency has gained a profound insight into the development as well as the ongoing challenges the higher education in Kazakhstan still faces in engineering, natural sciences and IT. Along several re-accreditations a European accreditation agency has been able to witness that the influence of central government control at least on some universities has been decreasing, thereby leaving certain spaces for more creative or alternative educative concepts and ideas. The required international accreditation (that is no longer the case), the mandatory introduction of English language programmes at all universities as well as the compulsory involvement of international (non-Russian) supervisors in PhD-projects stand witness for the political will to internationalize the higher education sector in Kazakhstan radically and, especially, to connect it to the European Area of Higher Education. The higher education institutions (HEI's) commitment in regard to the introduction of Bologna structures into Bachelor and Master programmes and increase of usage of European Credit Transfer System (ECTS) credits document during the last years allows adapting to European standards to become an attractive partner in international projects and mobility.

However, it should not be neglected that this transformation process has not processing (and still is not) without difficulties. Particularly, the introduction of programmes in English language is a challenge, especially in more rural areas where English classes in school are not often of the quality required to prepare students for successfully studying in this language. Furthermore, the language qualification of the teaching staff does not always comply with the requirements to teach. Above all, the significant brain drain especially in engineering field leaves the universities in a complicated situation where potential staff is either technically well qualified or speaks good English; finding applicants with both skills that are not regularly offered in attractive positions in the industry or outside the country is increasingly challenging and often limits the potential growth of otherwise flourishing institutions. In case of international partnerships, supervisors or mobility, finding suitable partners in Europe or Asia has equally proven difficult and would require more joint forums of Kazakh and international 
higher education representatives to establish a certain level of contact, understanding and trust.

Most importantly, in case of the accreditation periods a European accreditation agency has witnessed the changing economic circumstances that influenced and are still influencing Kazakh higher education. While in the beginning of a European accreditation agency's activities the dominance of oil and gas production and all technology accompanying these fields was overwhelming, leaving little room and funding for other programmes, this has slowly been shifting in recent years. While the dependence on gas is still prevailing, the decreasing gas prices and the growing inflation of the national currency (both closely connected to Russian economic politics) have led to shifting priorities at least in some areas. Around Almaty, Karaganda and Shymkent more IT-based companies have settled and require a growing number of skilled employees. All larger software companies maintain offices in at least one of the named locations, traditionally approving such advantages as sound mathematical training of Kazakh students as well as low salaries. To this need several (private) HEIs are dedicating themselves, International IT University in Almaty being the most prominent example. Within ten years this institution has been rapidly growing, providing qualified workers for the IT industry and eventually compelling the national government to copy its structure by installing an IT University in Nur-Sultan in 2019. The success of these institutions has turned out, at the same time, to be their major challenge. While traditional engineering and IT education in Kazakhstan is strongly focused on theoretical and mathematical foundations, these aspects are reduced to a minimum (if at all) in the newly developed programmes. These institutions where students pay comparatively high study fees with the promise of lucrative jobs afterwards have been taken up the German concept of Applied Higher Education in an extreme form and with little to none academic or scientific background. It has been regularly remarked that the academic level of these programmes is no longer comparable to programmes on EQF Level 6 or 7 , not to speak of the quality of $\mathrm{PhD}$ projects. This leads to a complicated situation that the envisaged internationalization of the programmes is hindered by their national success because in their academic quality they are now less attractive for partners in Europe.

After all, the Kazakh government has accepted this strongly practiceoriented approach and is now turning its attention to further developing this field. With no traditional professional training or education in companies the government plans on strengthening professional education in universities, comprising mere practical fields such as nursery or carpentry but also academicrelated fields such as IT and basic engineering. According to a European 
accreditation agency's understanding of the current developments in Kazakhstan, the situation could thus be summarized:

- For a closer connection to the European Areas of Higher Education, internationalization and English language are supposed to be strengthened but forums that offer an opportunity to network to HEIs as well as students are lacking.

- With the increasing demand of the IT industry several institutions have turned towards a strong practical institution but reducing academic contents to a radical minimum; this at the same time reduces the international compatibility of the programmes.

- Based on the success of the practice-oriented institutions the government tries to enhance practical education in a broad variety of fields throughout the country that were not taught at all or required a full academic qualification.

Thus, the next step of development would need to be the development of IT and Engineering based programmes that provide practical training (or full tracks) with academic training (PhD-tracks) while at the same time bringing them into contact with European institutions that are interested in supporting this academic development as well as receiving Kazakh students in their own institutions. Through this measure such programmes could close the gap between the lacking international networks, professional education and education of potential academic offspring.

Findings of the research based on structuring content analysis allow identifying that interaction between experts, educators and students and government in the field of engineering and IT in Kazakhstan's higher education is positive. The study results assist in finding that interaction between educators and students, on the one side, as well as enterprises, companies and industry, on the other side, should be enhanced in higher education in the field of engineering and IT in Kazakhstan.

Findings of the research based on summarizing content analysis allow determining that universities delivering higher education in the field of engineering and Information Technology (IT) in Kazakhstan need to balance academic and practical components in their study programmes.

\section{Conclusions}

Findings of theoretical analysis allow extending three-component model on needs analysis, namely experts' perspective, educators' perspective, and students' perspective by the fourth component, namely community perspective. 
Findings of the search for the main categories of the research field, namely higher education in the field of engineering and IT, resulted in identifying two main research categories such as

- Academic basis of higher education in the field of engineering and IT,

- Social interactions between social actors.

Findings of the empirical study allow drawing a conclusion that universities delivering higher education in the field of engineering and IT in Kazakhstan need to balance academic and practical components in their study programmes.

Implications for higher education in the field of engineering and IT in Kazakhstan lead to the establishment of

- closer connections to the European Areas of Higher Education via

- internationalization,

- use of English language,

- networking.

- balance between academic and practical components in study programmes.

- full track of higher education at a university that include

- Bachelor Degree study programmes,

- Master Degree study programmes,

- Doctor Degree study programmes.

The present study has some limitations. A limitation is participation of only one respondent from one European accreditation agency in the empirical study. Another limitation is that only one interview was conducted. The research question has been newly formulated: How to balance academic and practical components in higher education study programmes in the field of engineering and IT in Kazakhstan? Future research will focus on involvement of more respondents into the empirical study. Implementation of a descriptive research could assist in understanding of universities' needs in Kazakhstan. A comparative study of universities' needs in higher education in the field of engineering and IT in Kazakhstan (from the perspective of the university, employers and accreditation agency) could be carried out as well as.

\section{References}

Ahrens, A., \& Zascerinska, J. (2012). Perspective of Game Theory in Sustainable Development. In: Stasys Vaitekunas (Ed), ATEE Spring University 2012 Conference 20 Years of Sustainable Development: Learning from Each Other, Lithuanian University of Educational Sciences, Vilnius, Lithuania, May 3-5, 2012, 99-108.

Ahrens, A., Bassus, O., \& Zascerinska, J. (2013). Bi-professional Curriculum in Higher Education: Context Analysis. Proceedings of 6th ICEBE International Conference on Engineeirng and Business Education Innovation, Entrepreneurship and Sustainability, Windhoek, Namibia, 7 - 10 October 2013, 101-107. 
Ahrens, A., Gruenwald, N., Zascerinska, J., Zakirova, G., Yefimova, I., Kakabayev, A., Melnikova, J., \& Aleksejeva, L. (2018). Exploring ICT Education at Master Level in the Context of Advancement of Digital Ecosystem: The Case of Kazakhstan. Society. Integration. Education. Proceedings of the International Scientific Conference. Volume I, 17-27. DOI: http://dx.doi.org/10.17770/sie2018vol1.3147

Ahrens, A., Purvinis, O., Zascerinska, J., Miceviciene, D., \& Tautkus, A. (2018). Burstiness Management for Smart, Sustainable and Inclusive Growth: Emerging Research and Opportunities. IGI Global. DOI: 10.4018/978-1-5225-5442-4

Ahrens, A., Zascerinska, J., \& Melnikova, J. (2019). Method for the Construction of Students' Scientific Identity within English for Academic Purposes: The Case of International Students of Master Programme "Information and Electrical Engineering" at Hochschule Wismar. Society. Integration. Education. Proceedings of the International Scientific Conference. Volume I, Higher Education, 43-53. DOI: http://dx.doi.org/ 10.17770/sie2019vol1.3731

Ahrens, A., Zascerinska, J., Hariharan, R., \& Andreeva, N. (2016). Educators' Opinion on Webinars in Higher Education. Proceedings of the International Scientifical Conference Society, Integration, Education, Volume 1 Higher Education Pedagogy, 15-27.

Bassus, O., Ahrens, A., \& Zascerinska, J. (2015). Analysis of Engineering Students' Needs in Interdisciplinary Education. Proceedings of the 8th International Conference on Engineering and Business Education 8-9 October 2015, 26-31.

Budde, R. (2005). Mexican and Central American L.A. Garment Workers: Globalized Industries and their economic constraints. LIT Verlag Münster.

Cohen, L., Manion, L., \& Morrsion, K. (2003). Research Methods in Education. London and New York: Routledge/Falmer Taylor \& Francis Group.

Digital Kazakhstan. (2017). Government programme. Retrieved from https://digitalkz.kz/en/

Flyvbjerg, B. (2006). Five Misunderstandings About Case-Study Research. Qualitative Inquiry, 12(2), 219-245.

Krippendorff, K. (2004). Content Analysis. An Introduction to its Methodology. London: SAGE Publications.

Kroplijs, A., \& Rascevska, M. (2004). Kvalitatīvās pētniecības metodes sociālajās zinātnēs. Rīga: RaKa.

Mayring, P. (2004). Qualitative Content Analysis. In: U. Flick, E. Von Kardoff and I. Steinke (Eds.), A Companion to Qualitative Research (pp. 266-269). SAGE, UK, Glasgow.

Mayring, P. (2000). Qualitative Content Analysis. Forum Qualitative Sozialforschung / Forum: Qualitative Social Research, 1(2), Art. 20.

Thanh, N.C., \& Thanh, T.T.L. (2015). The Interconnection Between Interpretivist Paradigm and Qualitative Methods in Education. American Journal of Educational Science, 1(2), 24-27. Retrieved from http://www.aiscience.org/journal/ajes

Zascerinska, J. (2013). Development of Students' Communicative Competence within English for Academic Purposes Studies. Verlag: Mensch \& Buch. 